\title{
Managers, Consumers, Visitors: Roles of Caring Relatives in Emerging Home-based Eldercare in the Czech Republic'
}

\author{
Tereza Hronová, Adéla Souralová
}

\begin{abstract}
Each culture has a deeply rooted understanding of what constitutes the ideal for eldercare organization. This article investigates the role of family members in the delegation and provision of eldercare by private for-profit agencies in the Czech Republic. In this post-socialist country with a high level of intergenerational solidarity, a new market for eldercare has emerged in recent decades. We are interested in how the dominance of the family in eldercare provision is inscribed in the functioning of forprofit agencies and their caring practices. We examine how the role of family members whose elderly relatives receive paid care provided by private for-profit agencies is conceptualized by those who sell the care services, those who provide these services, and the care recipients themselves. We draw upon interviews conducted with the owners of private agencies, ethnographic observations, and informal interviews with paid care workers.
\end{abstract}

KEY WORDS $\quad$ eldercare, for-profit agencies, family members, Czech Republic

\section{Introduction}

Each culture has a deeply rooted understanding of what constitutes the ideal for eldercare organization. In general terms, eldercare work can be organized by four diverse actors the family, the state, charities, and the market (Stark 2005) - or by a combination of these actors. The bricolage of caring arrangements changes in particular historical, social, and cultural contexts and so does the preferred level of participation of the actors.

This article investigates the role of family in the delegation of eldercare and the provision of eldercare by private for-profit agencies in the Czech Republic. As a post-Communist country, the Czech Republic has a history of shifts between two preferred models of eldercare organization - defamilialism and institutionalism on the one hand and familialism on the other. Eldercare policies changed during the Communist period in the former Czechoslovakia from defamilializing tendencies (in the 1950s), towards explicit familialism

Sociální studia / Social Studies 2/2019. S. 7-24. ISSN 1214-813X.

1 This paper was created as a part of the research project "Fourth Age: The Identity of Disability During the Period of Active Ageing" supported by the Czech Science Foundation (GA15-03156S). 
(in the 1970s and 1980s), and finally to an implicit familialism in the post-socialist era ${ }^{2}$ (Mař́ková and Plasová 2012; Souralová and Šlesingerová 2018). The period after the fall of Communism (1989) included essential reforms in social services, introducing market principles into social care in 2006. These substantial changes occurred 20 years after similar changes in Western countries. The Czech Republic can be seen as one of the "latecomers in respect to the restructuring trends" (Kubalčíková and Havlíková 2016: 181).

Despite the turbulent changes in social policies, trends, and ideals regarding how, where, and by whom eldercare should be arranged, there seems to be a constant in the organization of eldercare: the family. There is still a dominant presumption that care should be given in the home and by relatives (Jeřábek 2009). In 2010, research conducted with 4,000 respondents showed that $78 \%$ of men and $82 \%$ of women agreed that children must take care of their elderly parents (Životní dráhy 2010). In 2009, Jeřábek concluded that the majority of the Czech population $(80 \%)$ had some experiences with family caregiving, and that $30 \%$ of that population provided or had provided care on a daily basis. In the Czech Republic, as in other countries, the obligation to provide eldercare is placed upon the women (the daughters most often) under the notion of intergenerational solidarity. Czech sociologists have continued to pronounce a high level of intergenerational solidarity (Možný et al. 2004; Sýkorová 2007).

The eldercare market is developing slowly under these sociocultural conditions. Institutional residential care continues to be the dominant method of long-term care organization in the Czech Republic. The principles of deinstitutionalization are only slowly being integrated - the participation of for-profit organizations is estimated to be three per cent in number of clients (Pfeiferová et al. 2013; Sowa 2010). The low interest in private paid care workers is the result of several factors, including poverty of seniors, lack of services in non-urban areas, and the fact that seniors are not used to playing the role of clients due to their experiences under the previous regime (Barvíková 2012; Souralová and Šlesingerová

2 The defamilializing tendencies were motivated by the efforts to emancipate women from household and domestic work and "their liberation from financial dependence on men was to be accomplished by introducing or pushing women into the labour market, paid work opportunities, and participation in the public sphere. All these efforts were meant to result in women being released from caring for dependent family members - including children and elderly people. These ideological expectations and the reasoning behind the shift to institutional and state forms of eldercare had even more pragmatic aims, such as to solve the housing crisis by providing a number of flats for young people when seniors have been settled in institutions" (Souralová and Šlesingerová 2018: 161; see also Maříková and Plasová 2012). However, it soon became apparent (in the 1960s and 1970s) that state socialism would not be able to offer enough effective institutional care for all people in need (Souralová and Šlesingerová 2018) and new models of eldercare organization were sought. In the mid-1970s, there was a shift toward explicit familialism, characterized, inter alia, by regulation No. 128/1975, according to which a monthly recurring financial benefit was introduced for persons caring for close dependent relatives (Neiderle 1996: 5). In the 1980s, eldercare was marked by implicit familialism: the state-run care system was insufficient and provided only low quality institutional care services and very limited home care (Souralová and Šlesingerová 2018; Maříková and Plasová 2012). 
2018). Finally, the low interest is because family members are seen as the primary people responsible for the provision of eldercare, and not fulfilling this ideal can be viewed as a personal failure. Dudová (2015) interviewed informal family caregivers, finding that they appreciate the possibility of being replaced for a while by a paid care worker as it allows them to continue to participate on the labour market without turning to institutional care (Dudová 2015). However, commercialized eldercare has a marginal status in Czech society. It is not a general cultural model of eldercare, and it is practiced by a tiny percent of citizens. Due to the high cost, it is rarely used as a full-time service but rather as a part-time solution to the care deficit.

In this article, we investigate the construction of the family responsibilities for eldercare and the role of informal caregivers in the context of paid eldercare work. We are interested in how the dominance of the family in eldercare provision is inscribed in the functioning of for-profit agencies and their caring practices. We investigate how the role of family members whose elderly relatives receive paid care provided by private for-profit agencies is conceptualized by those who sell the care services, those who provide these services, and the care recipients themselves. We study the role of family members indirectly, without interviewing them, because our aim is to see how their role is conceptualised by those who provide care and those who receive it. We explore the marketing strategies of the forprofit agencies as well as the very micro level of daily interaction between clients and care workers. To address these issues, we draw upon interviews conducted with the owners of private agencies, ethnographic observations of the interaction between paid care workers and care receivers, and informal interviews with paid care workers. This article contributes to the ongoing discussion about models of eldercare organization and illuminates how local conditions shape the local solutions to global issues of ageing, demographic changes, and care work provision.

\section{Conceptual framework: family and paid eldercare}

Paid home-based eldercare has become a topic of discussion in contemporary social sciences, although it is still less researched than paid child care. The growing research interest in this field is in reaction to the increasing demand for paid eldercare workers in many European countries. Studies published in the last three decades have covered especially the topic of asymmetrical relations, the class and ethnic hierarchies reproduced through paying for care, and the undervaluation of eldercare work (Solis 2015; Dahl 2017). For many scholars, care work is a symbol or at least an example of inequality in the globalized world (Hochschild and Ehrenreich 2003; Solis 2015). These studies are built upon the dominant image in which the employer is a white middle-class woman while the employee comes from a migrant background. The relationship between these two "may be affectionate and respectful, but it seems beyond doubt that one of the two parties - the employee - is in a more vulnerable position" (Solis 2015: 73).

Two essential issues in the current eldercare scholarship shaped our research interest and the analysis of our data. The first is the conceptualization of caregiving that includes care management (Archbold 1983; Rosenthal et al. 2007; James 1992; Brody 2004), 
and the second is the research on the relationships that develop in and through paid care work by the care workers, care managers, and care recipients. Even though both dimensions presume rather than exclude each other, they are not always necessarily connected in current research. For the purposes of our analysis, we find it important to put these two issues together and investigate how the care management may influence the perception of care relationships by care workers and care recipients.

In 1983, Archbold concluded that most of the literature on family caregiving focused almost exclusively on "hands-on" care while neglecting the care management of the family members (Archbold 1983). Rosenthal, Martin-Matthews, and Keefe (2007) observed that subsequent scholarship has not paid attention to the managerial aspects of family eldercare. In her study, Archbold (1983: 41) identified two types of carers for older people: family care providers who identify their parents' needs and perform the care themselves and care managers who identify the care needs and manage their provision by others. James (1992) created the formula "care = organization + physical labour + emotional labour" to address the importance of the organization of care and make it part of what is understood under the general term of care. James cited Sharpe's 1984 study: "It is ironic that the organisation involved in combining home, childcare and job would qualify many women for a management diploma, yet it goes unrecognised outside the home" (Sharpe 1984: 233; cited in James 1992: 493). James follows this thesis and adds that planning and organizing enable the effective arrangement of care and are necessary for both the caregiver and the care receiver.

A close investigation of the managerial aspects of care and an examination of its nature is provided by Rosenthal et al. (2007). They identified several important characteristics: the combination of care provision and care management in the daily life of family caregivers; the multidimensional character of care management, including orchestrating care; and financial and bureaucratic management. They found that managerial care is time consuming but less than the provision of care itself and that managerial care is associated with stress among women but not among men. They concluded that "managerial care is not a 'lesser' form of care which can be ignored because it has little impact on those who provide it” (p. 774).

Interpersonal and/or care relations and the shifting roles of those concerned in the provision of eldercare are big issues in contemporary societies where "under capitalism, paying for care - by the recipient, family members, a company or the state changes our relatedness to each other" (Dahl 2017: 31). The paid workers - invited either by care managers or by the care recipients themselves - enter the private realms of the people for whom they care and become part of their intimate sphere. Twigg (2000) argues for conceptualizing care work as body work, writing that "carework is about dealing with human wastes: shit, pee, vomit, sputum; and as such involves managing dirt and disgust" (p. 395). Care work includes very intimate tasks, skin-to-skin contact, dealing with nakedness etc. (see also Isaksen 2002). The care workers must negotiate the boundaries between intimacy and distance. Care work involves intimacy even beyond the terms of body proximity and touch; it also involves the social intimacy manifested in the development of ties based on mutual dependency and emotionality, resulting in the use of kinship terminology (Kraner 1999; Barnhart et al. 2014; Piercy 2000). In private home-based care, the care worker enters 
the intimate realm of the care recipient and becomes familiar with the household routines and private details of the care recipient's life, including social and health conditions, which are usually reserved for family members or friends (Karner 1999). In daily interactions, care workers and care receivers "invoke family imagery to convey meaning and to show how the relationship comes to function - like family" (Karner 1999: 75). Similarly, Piercy (2000) reported that over half of elderly people and their care workers considered their relationships as friendships and more than a third saw each other as being "like one of the family" (see Barnhart et al. 2014). Only a small amount of research focuses on how employers daughters, sons, or partners of elderly people - reflect upon these relationships and how they understand the care work as a job (Marchetti 2015; Solis 2015).

Sets of (often ambivalent) ties and relations between care workers and care receivers are negotiated in and through paid care work. The current scholarship does not make very clear how these relations differ when the eldercare is mediated by care placement agencies. Some inspiration can be found in the research on childcare placement agencies (Mendez 1999; Bakan and Stasiulis 1995; Souralová 2015). Mendez (1999: 118) depicts the particular character of bureaucratized care work as follows:

[in] the household service agency the work process is not controlled by an individual employer who is purchasing the labor of the worker, but by an organization that makes a profit from this labor. In certain respects, then, the addition of a profit-extracting organization to the employment arrangement transforms domestic work from being reproductive to being productive labor.

The agency therefore plays a crucial role in creating the first contact between care workers and care receivers, in supervising the whole process of caring, and in shaping the demand for this service generally.

\section{Study context and research design}

While "in most welfare states, elderly care is becoming part of a booming market" (Dahl 2017: 32), the market for care work is not expanding very rapidly in the Czech Republic - neither for child care nor eldercare (for other post-socialist countries, see e.g. Hrženjak 2012; Kindler 2008; Tkach and Hrženjak 2016, 2016; Souralová 2018). As mentioned above, only around three per cent of Czech families hire private eldercare workers; almost three decades after the fall of Communism, institutional residential care is the main actor in the field of formal eldercare. The majority of elderly people, however, are cared for informally by family members. The current eldercare market also differs from Western countries in the rarity or absence of migrant care workers. Some researchers suggest that it is only a matter of time before migrants enter this labour segment (Válková et al. 2010).

The costs of paying for professional care and providing informal care can easily cause increased poverty for seniors and their informal caregivers, and lead to an understanding of caregiving as a burden, resulting in unstable situations. The private agencies that we researched are run according to a business plan; one hour of services costs on average $120 \mathrm{CZK}$, which is slightly more than the average hourly wage in the Czech Republic and twice the minimum hourly wage. It is obvious that agency services are not affordable 
for everyone due to the high level of senior poverty; the price for round-the-clock service would be almost four times their total income. ${ }^{3}$ For these reasons, the typical model is that the agencies are used for several hours per week and the caregiver from the agency does not replace the caring family members but rather makes it possible to organize shifts/ changes with the family members (see also Hronová 2017; Souralová 2017; Souralová and Šlesingerová 2018).

We chose qualitative methods because they are suitable for understanding the processes of social construction (Silverman 1993). We employed three specific techniques in our research: analysis of the websites of for-profit agencies, in-depth interviews with the owners of the agencies, and episodic ethnography of the home-based care (including observations and informal interviews with care workers and care recipients). These techniques were combined in order to reveal the complex picture of the emerging supply of paid eldercare.

We performed an analysis of the websites of eldercare placement agencies. The sample of the websites was the same as the sample of the interviews, meaning that we analyzed the websites of the agencies whose owners we interviewed. These websites present several key aspects of the agency practices - marketization, creation of supply and demand, and the construction of the need for private eldercare. In our analysis, we were particularly interested in the rhetoric used to target clients and promote these care services. We conducted a critical discourse analysis in order to illuminate the ways the agencies construct eldercare and the supply for it. For this reason, we were particularly interested in the website's landing page, in the sections about the offer (titled e.g. "What we offer"), and in the information about the agency (usually titled "Who we are"). Our main interest was the self-presentation of each agency. The analysis of these websites was the initial phase of our research; it helped us to formulate the interview questions, and the information we obtained from the websites was directly addressed in the interviews and subjected to the interpretations of the interviewees.

The interviews were conducted with ten agency owners. As key actors in marketized eldercare, they are responsible for shaping the nature of eldercare and its principles and for creating the marketing strategies. The sampling strategy was twofold. First, we selected a regional capital with more than 100,000 inhabitants (for purposes of anonymization, we have omitted the name of the region). In the second phase, we created a list of agencies providing their services in this region (there were 12 agencies) and contacted their owners. In all, we conducted ten semi-structured interviews, as two owners refused to speak with us. The total number of ten interviews thus followed the logic of the market itself. These interviews focused on the following issues: the spectrum of services offered, the employee structure, communication and the process of setting up cooperation between agency and family, and the demand for agency services.

3 Counted as the average state pension + cash benefit for the 4th level of dependence; counted as $120 \mathrm{CZK} /$ hour, 24 hours per day, 30 days in a month (Souralová and Šlesingerová 2018). The average monthly pension in 2016 was 11,400 CZK (approximately 425 EUR) - 12,500 CZK for men and $10,300 \mathrm{CZK}$ for women. The monthly cash benefits for care in the same year were $880 \mathrm{CZK}, 4,400 \mathrm{CZK}, 8,800 \mathrm{CZK}$, and 13,200 CZK according to the four levels of dependence. 
The participant observation and informal interviews focused on the perspectives of care workers and care receivers. The procedure went as follows. We addressed an agency providing home-based eldercare. Following an agreement with the agency owner, four paid caregivers were selected to be accompanied by us during their daily work routine. The caregivers were all women between the ages of 40 and 65 with Czech citizenship. They worked as live-out care workers visiting five elderly clients per day on average. We spent a whole week with each caregiver, going with them to the homes of their elderly clients. In the course of one day, we visited several clients' homes and accompanied the caregivers as they conducted other activities connected with the services they provide, such as shopping, picking up medications, and visiting offices. Since the caregivers typically work from early morning to late afternoon and travel around the whole city, we also spent quite a lot of time in informal interviews about the nature of the job as well as about how they perceive the clients and their families. These informal interviews were a rich source of data. We participated in the daily routines of the care workers and their clients by helping with basic needs - making tea, helping to prepare meals, reading newspapers aloud, dressing, shopping and unpacking the shopping bags, buying medications or other small equipment (for example batteries), and talking to the elderly client's relatives about their actual condition and daily attitude. $^{4}$

We used these data sources to answer the following set of questions: In cases when family care is delegated to commercial actors, how is the role of the relatives defined? How do the key actors of paid care businesses - the agency owners, paid caregivers, and care recipients - perceive the role of the family? When the provision of care goes from informal to paid, what is the place of the family? Our analysis then focused on the meanings of family and the roles of family members as articulated in the interviews, both formal and informal, and during the observed interactions between care workers and care receivers. The findings of our analysis are presented in the subsequent sections.

The caregivers we accompanied were informed by their managers about the details of the research project as we had provided it to the manager. The manager, hence, was the main gatekeeper who took us to the particular care workers. After receiving the informed consent of the care workers, the care workers themselves conducted a second selection round by discussing the potential research participation directly with their elderly clients, as the care workers had the closest relationship with them. Due to the sensitivity of the topic, we left it up to the care workers to decide which clients we could visit with them and how they framed our presence in the clients' homes. The care workers took into consideration the physical and mental conditions of their clients and excluded some of them from the research themselves. Mostly, this was done because of mental illness, as such a visit could be unpleasant for us, as non-experts, and for the clients themselves. Some of the clients (with better mental well-being) refused to participate for personal reasons. Finally, where the care

4 In some cases, the relatives of elderly clients took advantage of the fact that a new person was present to discuss their views on how their older relative was doing or how their condition was perceived. Talking about the attitude of the client in a given day with the relatives is a common routine for the caregivers, and we sometimes became a part of this discussion. 
workers perceived it as appropriate, they introduced us as future care workers learning to care for the elderly in their homes. The reason for this story was mostly to allay the suspicious or distrustful attitude of the elderly clients towards strangers. All of the names in the article have been anonymized.

\section{Eldercare placement agencies and their services}

Private agencies providing eldercare are for-profit organizations that offer formal care in their clients' homes. They are commercial subjects, which means that their services must be ordered and paid for. The company owners define the agencies' goal as to help people who are not able to take care of themselves, either because of their age or due to some physical disability. The range of their services is quite wide, and includes helping with basic hygiene, getting dressed, shopping, cooking, basic cleaning, accompanying clients to doctors and offices, and ensuring social contact.

Probably the most emphasized service is the last one. Private agencies highlight that they offer social contact in contrast to other service providers. The aim of this service is to keep elderly people integrated in the society. The basic presumption is that elderly people tend to be alone not only physically by living on their own, but also socially by not having enough opportunities for contact with friends or relatives. The solution agencies offer is to provide a caregiver who focuses on practical help with cleaning and cooking, but who also talks to the care recipient and spends time with the client. From the perspective of the agencies, spending time with elderly people is a valuable service they are able to offer.

Emphasizing what for-profit agencies can provide in contrast to other actors providing eldercare is a common strategy used by for-profit agencies in publicizing their services. The intention might be solely descriptive - to show what they do and do not do. However, more often these distinctions are highlighted by agency owners in order to promote their agencies and sell their services.

Retirement homes are a significant competitor for in-home eldercare agencies. These provide regular and permanent care for older people directly. The basic difference between retirement homes and private agencies is that old people go into retirement homes to be taken care of, while agency care workers come to their clients' homes. When comparing the advantages and disadvantages of these two institutions, private agencies put a clear emphasis on the home environment, tending to favour maintaining the home setting as one of their principles.

Other alternatives to in-home agency care are private and public medical organizations. These provide expert care based on medical knowledge. Older people request this type of care on the basis of their doctor's recommendation. These organizations function as in-home medical care services, offering all medical procedures that do not have to be performed in a hospital and can be easily done at home. Such services include providing medications, re-bandaging injuries, and giving injections. As the character of these services suggests, these acts can only be carried out by certified nurses or medical assistants. One stated disadvantage of these institutions is the too formal and depersonalized attitude of the workers towards their clients; on the other hand, such institutions have the advantage of being able to provide 
expert care, which is a shortcoming of many private agencies. When asked whether the fact that private agencies do not provide medical care is a disadvantage, the owner of the Apple Agency replied:

Yes, maybe it is a minus for me that ... we don't provide medical care, that we only provide caring care. We only look after people, we don't provide medical treatment. ... If someone comes, they want us to nurse their parents, for example because they suffer from diabetes and someone needs to give them medication, but we don't do that.

This agency was quite an exception in that they only focused on the social aspect of care, excluding from the range of their services all medical assistance as well as helping with hygiene. The employee structure within most agencies was varied. Almost all other agencies employ nurses or medical assistants for when medical care is requested. Some of the employees thus help only with specific activities, while others are employed to provide everyday care, whether social or medical.

Voluntary organizations, charities, and church communities also provide for the elderly. These function as a sort of integrator, as their main activity is organizing social events where older people meet, talk, or play. From that point of view, they share ensuring social contact for elderly people with private agencies. For-profit agencies do not usually compare their services with this type of actor, which could be because they do not really provide care but rather a spectrum of leisure activities. As such, they are not a true competitor on the market for the for-profit agencies.

\section{Family members as clients, sponsors, or supervisors of private eldercare?}

In this section, we present the main findings of our analysis. On the websites, in the interviews, and in the field notes taken during the observations, we identified three main roles played by family members in delegated eldercare.

\section{Family members as clients of services}

The first issue we addressed in our analysis was the construction of the target client. We asked two questions: Who is targeted in the agencies' web presentation and how? and Who makes the initial contact with the agency? Investigating these questions illuminates how eldercare work services are designed and constructed and how the agency owners, care workers, and care receivers themselves make sense of it in the context of their expectations of how eldercare should be organized.

The care services are designed for and offered to "families," "family members," and "relatives." These keywords appear on all of the web pages that we analysed, and in the following contexts:

The purpose of this service is to provide family members time for relaxing, vacationing, and regenerating, as well as to give them the opportunity to keep their jobs. (Primrose website) 
Caregiving can be very exhausting and family members sometimes need to "turn off" and have a moment for themselves while knowing that their elderly parents are being taken care of at the same time. (Tulip website)

We try to ease the family situation by superseding the family caregiver in caring. (Tulip website)

These sentences demonstrate the marketing strategy of the agencies to present eldercare as a burden that weighs on the shoulders of families. These typical and repeating statements show two trends: 1 . They make the elderly people invisible. The elderly people are not present in the main slogans aimed to attract the attention of potential clients. They are present on the websites in images of smiling happy people surrounded by eldercare workers, or their role is demonstrated in the emphasis on the role of the agency in enabling them to stay at home and avoid institutional care. 2. Highlighting the needs of family members ("relaxing," "vacationing," "regenerating," "moment for themselves") and offering them the services which relieve them of the burden of care ("turn off," "ease the family situation").

In the interviews we conducted with the agency owners, the situation was similar. The way that the services are constructed on the websites and the very fact that they are advertised mainly on the Internet, which is the domain of the younger generation (only one agency reported that they use the strategy of distributing leaflets to attract clients), influences who usually initiates the first contact with the agency. Typically, we can observe a situation in which family members select an agency that could provide care and then present it to their elderly parents or other relatives. The central role of the younger relatives of the elderly client in contacting the agency is apparent in the following quotations from the interviews:

In most of the cases we communicate with the family of a senior, but there are also ones who take care about ordering a service and the family only helps them. (Snowdrop owner)

When I look at statistics, it is rather the children of elderly people who call us. (Peony owner)

Mostly these are family members who contact us first, hardly ever is it the care recipients themselves. (Tulip owner)

The interviews show that care services are mostly negotiated and organized by the family of the elderly client. The role of the family does not end with the initiation of paid eldercare. On the contrary, the service is typically described as the agency "alternates with the family members in caretaking." The majority of the agencies therefore do not see their role in replacing the family but in "being there to take turns with them." This follows their rhetoric that the service is aimed at family members. In practice, this means that the purpose of their service is to let the family members who are taking care of their elderly relatives to take a break, have a rest, and let paid caregivers to do the job instead of them for a while. The agencies depict the activity of caretaking as a demanding and stressful job that needs to be stopped after a while to have a rest. The same point was also made in the informal interviews with the care workers, who see themselves as helpers for the families. 
Some agency owners and care workers reported that the initial intention of sharing the eldercare responsibilities led to the transfer of eldercare from the relatives to the agency. They observed changes in the intensity of the family members' participation in the care and their transformation from carers into visitors. If elderly members of a family are being provided with paid care, their relatives typically visit them with some established weekly or monthly frequency, although their elderly relative expects them to come almost every day. We observed these mismatched expectations in several cases:

Ms. Červená knows what day it is when the caregiver asks her, but she wants it to be Saturday. On that day, her family typically comes to visit her, so she is looking forward to seeing them. She also has many calendars and clocks around her bed so that she can check the date all the time. (Field notes, 19 May 2016)

Ms. Bílá's son comes to visit her twice month. We suggest going for a walk with her caregiver since the weather is so nice, but she refuses, saying that her son is about to come and she does not want to miss him. (Field notes, 18 May 2016)

These two field note excerpts illustrate several key issues. Above all, there is the manifestation of the importance of family members for the elderly people. From the observations, it seems that the presence of paid eldercare workers mirrors the perceived lack of interest on the part of the family members. This was apparent in the observations in the home of Ms. Černá and her description of her relationship with her granddaughter. The intensity of frustration from insufficient contact with their relatives makes some of the elderly clients even stubborn and emotionally hurt, showing how important the visits are for them:

Ms. Černá complains about the fact that her granddaughter and great-grandchildren do not visit her, but when the caregiver suggests buying some candy in case they came, Ms. Černá replies that she does not care anymore. (Field notes, 17 May 2016)

From the perspective of the care workers, families, by fulfilling the role of visitors, can help to advance the cooperation of the caring triangle of family, elderly, and caregiver. This can be seen for example in the way that the caregiver might meet the family from time to time and set up some rules for providing care. In one home, the daughter of an elderly care recipient regularly wrote notes and comments for the caregiver, to change the caregiver's views about how to provide the best care. However, if the relatives and the caregiver do not meet, there are even bigger positives because it means that the family visits the elderly member and spends time with them. Moreover, as some of the caregivers reflected, some clients require everyday service and when family comes for a weekend it means the caregiver does not have to go there. In other words, even if caregivers are often seen as a semi-permanent or permanent substitute for family caregivers who are about to have a rest from caring, the whole process can work the other way round as well. By playing the role of visitors, family member can provide the caregivers with a time to rest. 


\title{
Family members as sponsors and financial guardians
}

Although private agencies comprise only three per cent of the care providers (Kubalčíková and Havlíková 2016), they seem to have the biggest business potential as they aim to make money, and adjust their promotional methods in order to do so. Agencies target the families of the elderly to buy the agency's services in order to ease the burden of caring. In parallel, they also transmit a signal towards the seniors. The average price for one hour of care services is about $120 \mathrm{CZK}$, a price that not every older person can afford to pay in the Czech Republic. For this reason, the relatives of the elderly client often play a significant role in the provision of care, managing the money in close coordination with the agency owners.

This can be seen as a side effect of the way the agencies promote their services. Each agency's website has a price list stating how much each particular service costs. The information is very detailed in defining what can be bought and at what price, and when the customers have to pay more. The most visible difference is between one-time and longterm caregiving. One-time services are more expensive, and there is a tendency among agency owners to explain and perhaps defend the higher tariff:

One-time caring is more expensive because the person calls on Friday afternoon asking for a caregiver for Saturday, Sunday, or Monday. That means this service is immediate - therefore I have to provide a caregiver to help these people much faster. This is why it is more expensive, because it is immediate. (Peony owner)

The agency owners overall highlight the fact that the relatives of the elderly clients typically pay for the services. This is interpreted by the agency owners as compensating for not doing the caring themselves.

In the direct interactions between the elderly clients and their care workers, the financial role of the family continues to be played on another level. The family members often function as "financial guardians," taking responsibility for dealing with paying bills and so on. This was seen in the home of Ms. Červená, where her family had an agreement with her caregiver to hide every bill that had to be paid so that Ms. Červená's children could pay the bills without her knowledge:

\begin{abstract}
When the caregiver brings leaflets and letters from downstairs, she goes to Ms. Červená's living room and hands over a TV magazine and some leaflets. Ms. Červená asks whether there were any letters. Ms. K replies there were not any and goes into the kitchen with a letter from the telephone company behind her back. She puts it in a glass box in the kitchen and explains that Ms. Červená's family will take care of it so that she does not have to worry about it. (Fieldnotes, 20 May 2016)
\end{abstract}

From the perspective of the elderly clients, the family might therefore function as a financial sponsor if relatives pay for the caring service as a whole, but also as a financial guardian if the money the family uses is not only their own, but the elderly client's as well. The role of relatives thus lies in managing these means and preventing their elderly relatives from being stressed by financial responsibilities. Worries about money are among the most frequent stressors for elderly people, as their caregivers report. For that reason, families also play an important role from the perspective of the caregivers as they help them to minimize 
factors that make elderly clients nervous, which would in turn make the caregivers' work harder to do. Ms. O (the caregiver for Ms. Červená) stated that she was glad to have such an agreement with the family, because otherwise she would have to calm down Ms. Červená every time a bill appeared. If families help with money issues, the caregivers' work with the client is a little easier to do. As we will see later on, the role of the family seems to take the form of irregular or abstract help, rather than active and frequent caring.

\section{Family members as supervisors}

Families have another role which complicates rather than eases the work of paid caregivers: the role of supervisors. This means they are typically in charge of everything, often regardless of the position of the caregivers. Although they do not spend much time with their elderly relatives, family members typically have a sort of "final vote" when it comes to decision making. Whether these are financial expenditures, such as buying extra equipment, or speaking with friends, the relatives have a strong voice which sometimes further complicates the everyday service of caring. The elderly clients often hold an observable sort of natural respect for their relatives' views, as seen in Ms. Černá's strong attachment to her son's view:

Ms. Černá replies that she is waiting for her son to decide... When she comes back, she is worried about whether he will arrive. Ms. K answers that he will because he promised to do so. (Fieldnotes, 18 May 2016)

This attitude could be partly understood as a side effect of insufficient contact with her family, specifically with her son. Ms. Černá often complained about being alone and indicated that her family did not come around very often. As a consequence, when the time for a visit was suggested, Ms. Černá did not want to miss her son, and she also waited for him to make all the necessary important decisions, such as organizing her trip to Slovakia, arranging a caregiver, and paying for all the services. From the perspective of her care worker, Ms. Černá's situation is quite complicated. On the one hand, her client expects her to pack her clothes and prepare everything for the trip; on the other, whenever the care worker wants to actually do anything or even suggests something, Ms. Černá wants to wait for her son to make the decision. In this case, the powerful influence of the relatives is not directly felt by the caregiver, but it is mediated through the elderly client's strong attachment to the relative's opinions and decisions, a situation which further complicates the provision of services by paid caregivers. Another example was seen in Ms. Šedás case, when there was a problem with a broken telephone:

Then she remembers she would like to call her second son, living in Prague, but the phone is off and she does not know how to fix it. Ms. S wonders why it is off and goes to check it. Ms. Šedá tells her to let it go because her son told her it was broken. The caregiver replies that the phone is just unplugged. Ms. Šedá shakes her head, apparently afraid to change anything. (...) Suddenly she says we should speak quietly because in this flat the walls have ears as well. The caregiver stops for a moment and looks at her closely, as she is not used to irrational thoughts coming from Ms. Šedá. She says that yesterday when she was talking with her friend, her son gave her the phone and then took it back again while listening to their whole conversation carefully. (Fieldnotes, 25 May 2016) 
Complications connected with the provision of caring services do not have only a material character. In cases like that of Ms. Šedá, the care workers get into a triangle with their client and the client's family, and often feel lost. On the one hand, their clients are often dependent on them and ask the caregivers to step up for them; on the other hand, the family demands a rational attitude and expects advice on how to deal with their elderly relative.

In some cases, the elderly clients are dropped out of this triangle, and the caregivers are put into direct opposition to the client's relatives. In such cases, the caregivers are usually defeated. This happens mostly in cases when the care services are provided to severely impaired people who suffer from some mental disease that makes impossible for them to communicate with either side. This was seen in Ms. Růžová's case:

The caregiver brings breakfast, gives it to Ms. Růžová, and sits in a chair to write notes and reply to the messages from Ms. Růžová's daughter in the notebook they keep together. The caregiver often finds various orders and wishes there, but often presented in a humorous context or including emoticons. (Fieldnotes, 1 June 2016)

We can see here another form of being in charge of the service of caring, although this case was a bit paradoxical in two ways. First, even though it might seem that the orders were given with goodwill and funny remarks, the caregiver herself reflected that while the emoticons were supposed to ease the orders, in fact she often had a lot of arguments with the daughter of the elderly client. Second, the client's family visited several times a week, but in the caregiver's view they absolutely did not care about the physical environment in which their (grand)mother lived. The caregiver often commented on the fact that the family did not do enough themselves, yet criticized her for leaving the windows open and so on. Situations in which the families did not respect the recommendations of the paid caregiver but instead tried to make the caregiver follow the family's suggestions occurred quite frequently. At the home of another client of this caregiver, we witnessed an intense and ongoing argument between the caregiver and the daughter and granddaughter of the elderly client that resulted from different views on the treatment she needed:

Ms. Fialová lies on the couch and falls off it constantly. The caregiver has to hold her all the time to prevent her from falling to the ground. Her family does not want to buy another couch or a bed, and they argue that she is used to it. The caregiver feels hopeless and reflects that even if she has experience, they do not trust her. She is sad and does not understand why nobody believes her that the woman needs either better equipment or all-day care service. (Field notes, 30 May 2016)

The daughter of Ms. Fialová often complains that she does not know what to do, but she does not respect the advice of the caregiver. She argues that she has been taking care of her mother for 12 years and knows what to do. (Field notes, 30 May 2016)

This scenario perfectly illustrates the impact of the family role as supervisors on the caregivers and their provision of care service. Since the family members have the "final vote," the caregiver has little chance to persuade them to implement any changes. In this case, the complications influence the nature of the caring service and impact the well-being of both the elderly client and the caregiver herself. Ms. Zelená told us she used to go to the home 
of Ms. Fialová three times a week, twice a day, but she started to suffer from back pain resulting from constantly lifting and holding Ms. Fialová and had to request less frequent visits. She admitted that she suffered under the unfriendly attitude of the relatives and would not go there anymore if she did not care so much about the woman.

\section{Concluding remarks}

This article investigated the delegation of eldercare work to private for-profit agencies. We focused on how the role of family members is conceptualized when the eldercare is transferred from the family members to the private market. Our interest in the role of family members had two origins: the prevailing intergenerational solidarity in the Czech Republic which leads to expectations regarding how eldercare should be organized within the family and the emergence of for-profit eldercare agencies as new actors in the Czech Republic. We analyzed interviews with agency owners, fieldnotes from observations in the homes of eldercare recipients, and informal interviews with care workers and care receivers, reaching several conclusions related to the developing eldercare market in the Czech Republic.

Although their services are used by only a small percentage of older people, eldercare placement agencies seem to be an important actor in the transformation of the patterns of eldercare in contemporary Czech Republic. The eldercare market builds upon the normative expectations that family members are the people who (should) care for their older relatives in the Czech Republic. The family is therefore both (partially) being replaced by the paid care workers and staying in the centre of the provided services. As previous research on family caregivers indicates (Dudová 2015), the eldercare placement agencies enable the family caregivers to care for the elderly while continuing their participation on the labour market. At the same time, the agencies support the step toward de-institutionalism and can postpone or even obviate the placement of the elderly in institutional nursing homes and - as the main catchwords with which they present their services online articulate - they enable older people to stay at home. However, given the fact that the services are quite expensive and they are usually purchased for a couple of hours per week rather than as 24/7 care, their services still must be accompanied by the presence of family members.

The family is the cornerstone of the business of the agencies. The family members play several roles in this care market. They are the recipients of the services, as the agencies present their offer as being services for the family members who can be relieved of the burden of care (see also Hronová and Souralová 2018). The family members are the sponsors, because they often pay for the provision of the services. In addition, they are an important communication partner for the agency. It is the family members who usually communicate with the agency, establishing all the conditions and further negotiating the services. For the agencies, the family members are much easier to communicate with than the elderly clients, as they are seen as the "younger and more rational" ones. This advantage, however, may turn into a disadvantage. Several caregivers reported that they are not respected if they share their advice or experiences with their elderly client's families and often are overruled when it comes to making decisions. Such situations are more delicate when the orders are given by relatives who are rarely in contact with the elderly client. This role of the family, 
as supervisors who always have the "final say," often complicates the provision of care for the caregivers. Even if the families are pleased to be available for their elderly relative, they can be hard to deal with for the caregivers.

Compared to other European countries, the marketization of eldercare is still a new phenomenon. Czech eldercare conditions today are still influenced by the pre-1989 situation when paid domestic work existed only to a limited extent and was intended for political and cultural elites; it was after the fall of Communism in 1989 and during the transition in the following years that many countries of the former Eastern bloc turned from the socialist welfare state to capitalism and so established "the structural conditions for an expansion of paid domestic and care work in private households" (Tkach and Hrženjak 2016: 6). The countries of the former Eastern bloc are usually seen as a source of supply of (migrant) care work abroad (see e.g. Bahna [2014] on Slovak eldercare workers in Austria), rather than countries with meaningful domestic demand. However, the demand for non-family eldercare workers is increasing even in these countries (Hronová 2017) and it can be expected that paid eldercare will become a more relevant issue in coming years.

Our investigation of perceptions of the role of family members in marketized eldercare in the Czech Republic shows the ambivalent role of family members in the process of care provision. The informal family caregivers remain in the centre while at the same time they are replaced by the paid care workers. The marketization of care therefore does not lead to or equate with the defamilization of eldercare. The future development of the eldercare market will show whether the role of the family in caring will be weakened and the share of paid service will increase, with paid care provided in intensive live-out or even live-in form. Another question is whether the market will be opened to migrant women, as is common in many European countries. This would raise the question of how such arrangements will influence the strong position of the family. For now, our findings indicate that the family is accompanied rather than replaced by paid care workers and that formal and informal caregivers work in symbiosis, although in many cases they never meet personally.

\section{References}

ARCHBOLD, Patricia G. 1983. "Impact of Parent-caring on Women." Family Relations 32(1): 39-45. BAHNA, Miloslav. 2014. "Slovak Care Workers in Austria: How Important Is the Context of the Sending Country?" Journal of Contemporary European Studies 22(4): 411-426.

BAKAN, Abigail B. and Daiva K. STASIULIS. 1995. "Making the Match: Domestic Placement Agencies and the Racialization of Women's Household Work." Signs: Journal of Women in Culture and Society 20(2): 303-335.

BARNHART, Michelle, Aimee Dinnin HUFF, and June COTTE. 2014. "Like a Member of the Family: Including and Excluding Paid Caregivers in Performances of Family." Journal of Marketing Management 30(15-16): 1680-1702.

BARVÍKOVÁ, Jana. 2011. "Long-term Care in the Czech Republic: On the Threshold of Reform." Pp. 81-103 in Long-Term Care in Central and South Eastern Europe, edited by A. ÖSTERLE. Frankfurt am Main: Lang. 
BRODY, Elaine. 2004. Women in the Middle: Their Parent-Care Years, 2nd ed. New York: Springer Publishing Company.

DAHL, Hanne M. 2017. Struggles in (Elderly) Care: A Feminist View. London: Palgrave Macmillan.

DUDOVÁ, Radka. 2015. Postarat se ve stáří. Rodina a zajištění péče o seniory [Care During Old Age. Family and Ensuring Senior Care]. Prague: SLON.

HOCHSCHILD, Arlie R. and Barbara EHRENREICH, eds. 2003. Global Women: Nannies, Maids, and Sex Workers in the New Economy. New York: Metropolitan Books.

HRONOVÁ, Tereza and Adéla SOURALOVÁ. 2018. "Eldercare Agencies and the Marketing of Care Work in the Czech Republic: Relieving a Family Burden?." International Journal of Care and Caring 2(2): 235-251.

HRONOVÁ, Tereza. 2017. "Becoming a Burden: Eldercare under the Effects of Commercial Strategies of Profit Agencies." Masaryk University, Brno. Masters thesis.

HRŽENJAK, Majda. 2012. "Hierarchization and Segmentation of Informal Care Markets in Slovenia." Social Politics: International Studies in Gender, State and Society 19(1): 38-57.

ISAKSEN, Lise Widding. 2002. "Masculine Dignity and the Dirty Body." Nora: Nordic Journal of Women's Studies 10(3): 137-146.

JAMES, Nicky. 1992. "Care = Organisation + Physical Labour + Emotional Labour." Sociology of Health and Illness 14(4): 488-509.

JEŘÁBEK, Hynek. 2009 “Rodinná péče o seniory jako 'práce z lásky’: nové argumenty [Family Care for Seniors as a 'Labour of Love' - New Arguments]." Sociologický časopis/Czech Sociological Review 45(2): 243-265.

KARNER, Tracy X. 1998. "Professional Caring: Homecare Workers as Fictive Kin.” Journal of Aging Studies 12(1): 69-82.

KINDLER, Marta. 2008. "Risk and Risk Strategies in Migration: Ukrainian Domestic Workers in Poland.” Pp. 145-159 in Migration and Domestic Work, edited by H. LUTZ. Aldershot: Ashgate.

KUBALČÍKOVÁ, Kateřina and Jana HAVLÍKOVÁ. 2016. "Current Developments in Social Care Services for Older Adults in the Czech Republic: Trends Towards Deinstitutionalization and Marketization." Journal of Social Service Research 42(2): 180-198.

MARCHETTI, Sabrina. 2015. “"Mum Seems Happy': Relatives of Dependent Elders and the Difficult Task of Employing a Migrant Care Giver.” Pp. 93-110 in Paying for Care: Employers, Agencies and Immigration, edited by A. TRIANDAFYLLIDOU and S. MARCHETTI. Farnham: Ashgate.

MAŘÍKOVÁ, Hana and Blanka PLASOVÁ. 2012. "Kontinuita anebo změna v systému zajištění péče o seniory v České republice od roku 1948 vzhledem k genderovanosti politik péče [Continuity or Change in the Senior Care System in the Czech Republic after 1948, Considering Gendered Care Policies]." Fórum sociální politiky 6(3): 2-7.

MENDEZ, Jennifer B. 1998. "Of Mops and Maids: Contradictions and Continuities in Bureaucratized Domestic Work." Social Problems 45(1): 114-135.

MOŽNÝ, Ivo, Marie PŘIDALOVÁ, and Lenka BÁNOVCOVÁ. 2004. "Mezigenerační solidarita, výzkumná zpráva $\mathrm{z}$ mezinárodního srovnávacího výzkumu 'Hodnota dětí a mezigenerační solidarita' [Intergenerational Solidarity, Research Report from International Comparative Study 'Value of Children and Intergenerational Solidarity']. Prague: Research Institute for Labour and Social Affairs.

PFEIFEROVÁ, Štěpánka, Martin LUX, Tomáš DVOŘÁK, Jana HAVLÍKOVÁ, Martina MIKESZOVA, and Petr SUNEGA, eds. 2013. Housing and Social Care for the Elderly in Central Europe: WP 3 Main Findings Report. Prague: Institute of Sociology, Academy of Science of the Czech Republic. Retrieved May 22, 2018 (http://www.central2013.eu/fileadmin/user_upload/Downloads/outputlib/ HELPS_Main_Findings_Report.pdf). 
PIERCY, Kathleen W. 2000. "When It Is More Than a Job: Close Relationships between Home Health Aides and Older Clients." Journal of Aging and Health 12(3): 362-387.

ROSENTHAL, Carolyn, Anne MARTIN-MATTHEWS, and Janice KEEFE. 2007. "Care Management and Care Provision for Older Relatives Amongst Employed Informal Care-givers." Ageing and Society 27(5): 755-778.

SOLIS, Cristina V. 2015. "Dilemmas of Paid Home-care for the Elderly in Spain: Daughters, Elderly and Domestic Employees." Pp. 73-93 in Paying for Care: Employers, Agencies and Immigration, edited by A. TRIANDAFYLLIDOU and S. MARCHETTI. Farnham: Ashgate.

SOURALOVÁ, Adéla and Eva ŠLESINGEROVÁ. 2017. "Post-socialist Eldercare in the Czech Republic: Institutions, Families, and the Market." Pp. 159-170 in The Routledge Handbook to Care Work Around the World, edited by K. CHRISTENSEN and D. PILLING. New York: Routledge.

SOURALOVÁ, Adéla. 2015. “An Employer Sui Generis: How Placement Agencies are Changing the Nature of Paid Childcare in the Czech Republic.” Pp. 151-167 in Employers, Agencies and Immigration: Paying for Care, edited by A. TRIANDAFYLLIDOU and S. MARCHETTI. Farnham: Ashgate.

SOURALOVÁ, Adéla. 2017. Péče na prodej. Jak se práce z lásky stává placenou službou [Care for Sale. How Labours of Love Turn into Paid Service]. Brno: MUNI Press.

SOWA, Agnieszka. 2010. “The Long-Term Care System for the Elderly in the Czech Republic.” ENEPRI Research Report.

STARK, Agneta. 2005. "Warm Hands in Cold Age - On the Need of a New World Order of Care." Feminist Economies 11(2): 7-36.

SÝKOROVÁ, Dana. 2007. Autonomie ve stáři [Autonomy in the Old Age]. Prague: Sociologické nakladatelství.

TKACH, Olga and Malda HRŽENJAK. 2016. "Paid Domestic Labour in Postsocialist Contexts: Regional Traits of a Global Phenomenon: An Introduction.” Laboratorium: Russian Review of Social Research 3: 4-14.

TWIGG, Julia. 2000. "Carework as a Form of Bodywork." Ageing and Society 20(4): 389-411.

VÁlKOVÁ, Monika, Marie KOJESOVÁ, and Iva HOLMEROVÁ. 2010. "Diskusní materiál k východiskům dlouhodobé péče v České republice [Discussion Materials Concerning Solutions for Long-Term Care in the Czech Republic].” Prague: Ministry of Labour and Social Affairs.

\section{Authors}

Tereza Hronová graduated the MA programme in Sociology at the Faculty of Social Studies, Masaryk University. In her studies, she focused on the issues of ageing and eldercare. In her research she dealt with the marketization of care and the role of family in care provision.

Contact: hronova.tereza@gmail.com

Adéla Souralová is Assistant Professor at the Department of Sociology, Faculty of Social Studies, Masaryk University. In her research she focuses on care, family, and kinship. She is the principal investigator of a research project on three-generation cohabitation in the Czech Republic.

Contact: asouralo@fss.mun.cz. 